DOI: 10.20472/IAC.2017.034.009

NICOLENE BARKHUIZEN

North-West University, South Africa

MOKHETHI PAULUS MATOBAKO

Southern Business School, South Africa

\title{
LEADERSHIP TALENT MINDSET AS A PREDICTOR OF THE MOTIVATION AND RETENTION OF JUNIOR CORRECTIONAL OFFICIALS
}

\begin{abstract}
:
The main objective of this research was to determine whether leadership talent mind-set is a predictor of the motivation and retention of junior correctional officials. A cross-sectional research design was followed with a Talent Retention Measure, Employee Motivation Survey and Employee Retention questionnaire distributed among a sample of junior correctional officials $(N=219)$. The results revealed that all talent management practices are currently poorly applied in correctional services. The respondents showed relatively high levels of intrinsic motivation. The results showed that all talent management practices were significantly related to motivation. Motivation moderated the relationship between talent management and turnover intentions of the participants. Recommendations are made.
\end{abstract}

\section{Keywords:}

Government, Junior Correctional Officials, Motivation, Talent Management, Retention

JEL Classification: J24 


\section{Introduction}

South Africa currently experiences a significant loss of key correctional services staff caused by resignations, terminations and death of officials (Department of Correctional Services, 2016). Consequently the community safety of South African citizens are threatened because of a shortage of available correctional service officials to protect them. Talent management has been identified as a useful concept that the security industry can embrace to manage key and competent individuals more effectively (Chiloane \& Barkhuizen, 2017).

The main objective of this research was to determine whether leadership talent mind-set is a predictor of the motivation and retention of junior correctional officials. The available research in the Southern African context paints a bleak picture as far as leadership commitment towards talent management is concerned. Most research to date in government institutions shows a considerable lack of management commitment towards the talent management of their employees (Barkhuizen, 2015). Research in particular shows that executives do not spend sufficient time in strengthening talent pools; neither are they properly trained in the best practices and latest techniques to develop, mentor and nurture talent (Barkhuizen, Welby-Cooke, Stanz and Schutte, 2014; Schutte, Barkhuizen \& van der Sluis, 2015). The important role of managers in creating a compelling talent value proposition for their employees have been documented (Saurombe, Barkhuizen, \& Schutte, 2017). Therefore a study investigating the outcomes of leadership talent mind-set towards employees are imperative if correctional services are serious about acquiring and retaining their talent.

\section{Literature review}

\section{Talent, Talent Management and Talent Mind-set}

The concept of talent remains fuzzy in academic literature and the application thereof in the workplace problematic. A recent study in a local government institution revealed that most of the participants confused talent as a term reserved for the popular media and lacked an understanding of its definition in the context of the workplace (Lubinda, Barkhuizen \& Schutte, 2017). A further debate is sparked regarding the application of "talent" for all employees or a selected view. The so-called elitist approach views talent as a concept only reserved for a selected few who are exceptional performers and can contribute to the strategic goals of the organisation (see Barkhuizen, 2015). Unfortunately this approach may overlook and ignore other potential talent in the organisation. Moreover, the question remains whether an organisation can really follow an elitist approach in a democratic South African dispensation with its various Labour legislations (Barkhuizen, 2015). The inclusivity approach view talent as a concept applicable for all employees in the workplace - everyone has the potential to be a talent and contribute to the organisation. However, this approach limits the fast-tracking of high potentials and high performers and may result in turnover intentions of talented employees. 
Consequently the misinterpretation of talent also challenges the effective application of talent management practices in the workplace. Talent management has been conceptualised in various ways but basically boils down to a set of integrated organisational workforce processes designed to attract, develop, motivate and retain productive, engaged employees (Massie, 2015). The goal of talent management is to create a high-performance, sustainable organisation that meets its strategic and operational goals and objectives. Organisations are required to develop, implement and manage well-planned talent management strategies and policies if they are to manage talent effectively (Swanepoel, Erasmus \& Schenk, 2014).

According to Mullins (2013) talent management requires senior management endorsement in order to succeed. It follows that managers should understand the concept of talent management, be responsible for talent management and be encouraged to adopt a talent mind-set that regards talent as an important corporate resource. Egerová, Eger, Jiřincová, Lančarič, Savov et al. (2013:20) describe a talent mind-set as "a deep seated belief that talent at all levels allows a company to outperform its competitors." Leaders are required to understand the impact of talent management on the organisation and the value that exceptional talent can add to achieve its objectives (Capelli, 2008). Leaders should adopt a new talent mind-set towards the workplace that is grounded by new leadership approaches, strategies and capabilities (Cheese, Thomas \& Craig 2008).

\section{Consequences of Leadership Talent Mind-set in the workplace Leadership Talent Mind-set and positive work related outcomes}

There are some evidence that management support for talent management can yield positive results for both individuals and organisations. Saurombe (2015) found that management commitment towards talent management enhanced the happiness and meaningfulness of academic staff members and reduced their turnover intentions. Studies by Mpofu (2013) and Pienaar (2013) showed that management involvement in talent management enhanced organisational energy and significantly reduced employees' intention to quit their jobs. Masale, Barkhuizen and Mokgele (2016) as well as Magolego, Barkhuizen and Mokgele (2013) found that the effective application of talent management practices enhanced the performance of employees.

This research focuses on intrinsic motivation as a positive behavioural outcome of leadership talent mind-set. In the context of this study we define motivation as the force within individuals that drives them to achieve their goals in order to fulfil some need (Mullins \& Christy, 2013). According to Cran (2010) factors such as personable and friendly relationships within the working environment, team activities and opportunities to contribute to the society seem to motivate millennials. Despite a proliferation of research on various motivational theories in the workplace and the antecedents of employee 
motivation, studies on its relationship with talent management remain scarce. Barkhuizen, Smit and Schutte (2015) found that talent management practices such as Management commitment, talent review processes, workforce planning, staffing, talent acquisition, talent development, performance management and retention strategies enhanced the motivation of support staff in a higher education institution. Intrinsic motivation factors further contributes to the retention of employees (Asad \& Dainty, 2005).

\section{Employee Retention}

Mengei (cited in Van Dyk \& Coetzee, 2012) define retention as an organisation's efforts to keep those employees of whom the organisation has a positive evaluation in their employment. According to Messmer (2006) retention can be improved when employees are offered compensation and benefits, have a supportive work culture and experience a sense of work-life balance. Talent management has been consistently related to the retention of employees in South African organisations. Studies by Barkhuizen and colleagues (see Barkhuizen, 2015) showed that factors such as a lack of management commitment towards talent, poor workforce planning, poor performance management and career development, and a lack of retention practices are prominent predictors of employees' intentions to quit their jobs.

There are some research to highlight the importance of management support in the retention of younger generation employees. Pop, Swanepoel and Barkhuizen (2013) found that the availability of mentorships programmes significantly enhanced the employability and retention of graduate interns in an information, technology and communication company. Du Plessis, Barkhuizen, Stanz and Schutte (2015) found that management support towards talent management, plays a critical role in the retention of Generation $\mathrm{Y}$ employees in a call centre environment. A study by Lesenyeho (2017) showed that the availability of management enhanced the organisational commitment of early career academics and reduced their turnover intentions.

In the light of the preceding text the following hypotheses are set:

$\mathrm{H}$ 1: There would be a significant positive relationship between talent management and the motivation of junior correctional officials

$\mathrm{H}$ 2: There would be a significant negative relationship between talent management and the turnover intentions of junior correctional officials

H 3: There would be a significant negative relationship between the motivation and turnover intentions of junior correctional officials 


\section{Research design}

\section{Research approach}

The research design followed in the present study is quantitative in nature. Burns and Grove (2005) describe quantitative research as a formal, objective, systematic process in which numerical data are used to obtain information about the world. This research method is used to describe variables; to examine relationships among variables; and to determine cause-and-effect interactions between variables. The present research is also be correctional, in the sense that it sets out to determine the extent of a relationship between two or more variables using statistical data. A survey questionnaire was used to collect data, in order to solicit the opinions and perceptions of the participants in terms of the Leadership Talent Mind-set as a predictor of the motivation and retention of junior correctional officials.

\section{Research participants}

The present study focused on Correctional Officials between salary levels two and twelve. The Correctional Officials who participated in the study are employed in six regions, namely the Western Cape; Eastern Cape; Kwazulu Natal; the Free State and the Northern Cape; Limpopo, Mpumalanga and the North West, and Gauteng. This choice was based on the recommendations of the Research and Ethics Committee of the Department Of Correctional Services. The target set for the study was 300 respondents, but only $219(\mathrm{~N}=219)$ responses were received and analysed, which gave a total response rate of $73 \%$. Most of the participants in the sample were female $(51,6 \%)$ with Indigenous language $(74,4 \%)$ as their home language. The participants were primarily representative of the Black African ethnic group (73,1\%), aged between 40 to 49 years and in possession of an undergraduate qualification (62,1\%). Most of the participants were employed on supervisor level (65,3\%), had work experience from 6 to 10 years $(41,1 \%)$ and employed between 0 to 5 years in their current job $(73,1 \%)$. Most of the participants had no change of promotion during the past five years $(80,8 \%)$ and worked between 21 to 40 hours in a work week (45,7\%).

Permission was obtained from the Research and Ethics Committee of the Department of Correctional Services to conduct the research. This research meets all requirements for ethical research. 
Table 1: Demographic characteristics of the sample

\begin{tabular}{|c|c|c|c|}
\hline Variable & Category & Frequency & Percentage \\
\hline \multirow[b]{2}{*}{ Gender } & Male & 105 & 47.9 \\
\hline & Female & 113 & 51.6 \\
\hline \multirow[b]{3}{*}{ Home language } & Afrikaans & 27 & 12.3 \\
\hline & English & 29 & 13.2 \\
\hline & Indigenous & 163 & 74.4 \\
\hline \multirow[b]{4}{*}{ Race } & African & 160 & 73.1 \\
\hline & Coloured & 19 & 8.7 \\
\hline & Indian & 9 & 4.1 \\
\hline & White & 28 & 12.8 \\
\hline \multirow[b]{4}{*}{ Age } & 20 to 29 years & 15 & 6.8 \\
\hline & 30 to 39 years & 88 & 40.2 \\
\hline & 40 to 49 years & 91 & 41.6 \\
\hline & 50 years and above & 25 & 11.4 \\
\hline \multirow[b]{3}{*}{ Highest qualification } & Grade 12 /Matric & 82 & 37.4 \\
\hline & $\begin{array}{l}\text { Diploma, Advanced } \\
\text { Diploma and Bachelor's } \\
\text { Degrees }\end{array}$ & 136 & 62.1 \\
\hline & Master's Degree & 1 & .5 \\
\hline \multirow[b]{3}{*}{ Job level } & Middle Management & 27 & 12.3 \\
\hline & Lower Management & 49 & 22.4 \\
\hline & Supervisor & 143 & 65.3 \\
\hline \multirow[b]{4}{*}{ Work experience } & 0 to 5 years & 80 & 36.5 \\
\hline & 6 to 10 years & 90 & 41.1 \\
\hline & 11 to 15 years & 35 & 16.0 \\
\hline & 16 years and above & 14 & 6.4 \\
\hline \multirow[b]{4}{*}{ Years in current job } & 0 to 5 years & 160 & 73.1 \\
\hline & 6 to 10 years & 47 & 21.5 \\
\hline & 11 to 15 years & 10 & 4.6 \\
\hline & 16 years and more & 2 & .9 \\
\hline \multirow[b]{4}{*}{ Chances for promotion } & 0 & 177 & 80.8 \\
\hline & 1.0 & 27 & 12.3 \\
\hline & 2.0 & 14 & 6.4 \\
\hline & 3.0 & 1 & .5 \\
\hline \multirow[b]{3}{*}{ Hours work per week } & 0 to 20 hours per week & 100 & 45.7 \\
\hline & 21 to 40 hours per week & 101 & 46.1 \\
\hline & 40 hours and more & 18 & 8.2 \\
\hline
\end{tabular}




\section{Measuring Instruments}

The following measuring instruments were used in this study:

Talent Management: A talent management measure was used to assess the respondents' perceptions of talent management practices in correctional services (Barkhuizen, 2015). The measure consisted of 60 items and measured 12 talent management practices: Talent review process, Management commitment, Workforce Planning, Talent Management Strategy, Talent outsourcing, Talent Acquisition, Talent engagement, Talent development, Talent performance talent retention and integrated talent management. Respondents were requested to evaluate the current application of talent management practices in the organisation on a 5-point Likert scale ranging from Poor (1) to Excellent (5). Acceptable reliabilities were found for the measure in various South African studies (see Barkhuizen, 2015).

Employee Motivation Scale: An Employee Motivation Scale was developed by the author to measure the motivation of junior correctional officials. The scale covers nine facets of motivation, but due to the fact that the shortened questionnaire only measured one item per facet, all items was joined to obtain a total score. The EMS also used a 5point Likert-type scale ranging from Strongly Disagree (1) to Strongly Agree (5).

Employee Retention Scale: The final questionnaire used in the study was an Employee Retention Scale. This scale consists of three items which are used to determine junior correctional officials' intent to quit the organisation. The respondents in the study were asked to rate the items on a 7-point Likert scale, ranging from Strongly Disagree (0) to Strongly Agree (6). This questionnaire has been validated for the South African context (Theron, Barkhuizen \& Du Plessis, 2014).

\section{Research procedure}

Written permission was submitted to request for an approval from the Research and Ethics Committee of the Department of Correctional Services to conduct the research. The written approval was granted by the Research and Ethics Committee. Standardised types of questionnaires were developed and distributed to the Departmental employees, specifically junior correctional officials. The participants of the study were randomly selected in the regions by the respective Human Resource Components. The questionnaires were sent electronically while some were hand-delivered to the regions to 
be given to the participants. The researcher and the respective HR components reached an agreement on the method to follow when returning the questionnaires after completion. The questionnaires were either emailed or hand-delivered to the researcher. The confidentiality of the participants was maintained, as no one was requested to disclose their identity.

\section{Statistical analyses}

Statistical analysis was carried out using the SPSS Program (SPSS, 2017). Descriptive statistics (i.e. means, standard deviation, skewness and kurtosis) were applied. The reliability of the measures was determined by means of Cronbach alpha coefficients. Linear and multiple regression analyses were used to determine the predictive relationships between leadership talent mind-set, motivation and intention to quit.

\section{Results}

The descriptive statistics and reliabilities of the talent management measure, motivation and intention to quit are reported in Table 2 below.

Table 2: Descriptive statistics of the measurements

\begin{tabular}{lccccc}
\hline & Mean & SD & Skewness & Kurtosis & $\alpha$ \\
\hline Talent management & & & & & \\
Talent review process & 2,4411 & 1,00474 &, 242 &,- 832 &, 903 \\
Management commitment & 2,4082 &, 94865 &, 048 &,- 941 &, 910 \\
Workforce planning & 2,4183 & 1,00368 &, 213 &,- 833 &, 910 \\
Talent management strategy & 2,5443 &, 99945 &,- 023 &,- 908 &, 907 \\
Talent outsourcing & 2,3553 &, 88970 &, 125 &,- 903 &, 900 \\
Talent acquisition & 2,3963 &, 94256 &, 210 &,- 727 &, 896 \\
Talent engagement & 2,5132 &, 97414 &, 051 & $-1,019$ &, 904 \\
Talent development & 2,4575 &, 99049 &, 209 & $-1,062$ &, 899 \\
Talent performance & 2,4329 &, 73473 &, 020 &,- 883 &, 601 \\
Talent deployment & 2,3863 &, 97698 &, 136 & $-1,144$ &, 922 \\
Talent retention & 2,2521 &, 96414 &, 234 & $-1,150$ &, 919 \\
Integrated talent management & 2,3279 &, 89755 &, 059 & $-1,024$ &, 926 \\
Motivation & 3,7826 & 1,23803 &,- 462 &,- 464 &, 832 \\
Intention to quit & 3,5875 & 2,05972 &,- 401 & $-1,187$ &, 916 \\
\hline
\end{tabular}


The results shown in Table 2 demonstrate that all talent management practices are currently poorly applied in correctional services. The respondents showed relatively high levels of motivation. Almost half of the respondents considered quitting their jobs.

\section{Testing of hypothesis}

The next section reports on the results in terms of the hypotheses. Linear regression analysis was applied to test the predictive relationships between the variables. The results of the interactive relationship between Talent Management and Motivation are reported in Table 3.

Table 3: Regression analyses between Talent Management and Motivation

\begin{tabular}{lccccccc}
\hline & Df & $\mathbf{F}$ & $\mathbf{R}$ & $\begin{array}{c}\mathbf{R} \\
\text { square }\end{array}$ & $\begin{array}{c}\text { Adjusted R } \\
\text { square }\end{array}$ & Beta & $\mathbf{P}$ \\
\hline Talent review process & 1 & 45,285 & $.416^{\mathrm{a}}$ &, 173 &, 169 &, 416 &, 000 \\
Management commitment & 1 & 60,713 & $.468^{\mathrm{a}}$ &, 219 &, 215 &, 468 &, 000 \\
Workforce planning & 1 & 76,102 & $.510^{\mathrm{a}}$ &, 260 &, 256 &, 510 &, 000 \\
Talent management strategy & 1 & 64,382 & $.478^{\mathrm{a}}$ &, 229 &, 225 &, 478 & $.000^{\mathrm{b}}$ \\
Talent outsourcing & 1 & 34,442 & $.370^{\mathrm{a}}$ &, 137 &, 133 &, 370 &, 000 \\
Talent acquisition & 1 & 42,734 & $.406^{\mathrm{a}}$ &, 165 &, 161 &, 406 &, 000 \\
Talent engagement & 1 & 63,418 & $.476^{\mathrm{a}}$ &, 226 &, 223 &, 476 &, 000 \\
Talent development & 1 & 56,871 & $.456^{\mathrm{a}}$ &, 208 &, 204 &, 456 &, 000 \\
Talent performance & 1 & 36,910 & $.381^{\mathrm{a}}$ &, 145 &, 141 &, 381 &, 000 \\
Talent deployment & 1 & 47,136 & $.422^{\mathrm{a}}$ &, 178 &, 175 &, 422 &, 000 \\
Talent retention & 1 & 37,318 & $.383^{\mathrm{a}}$ &, 147 &, 143 &, 383 & $.000^{\mathrm{b}}$ \\
Integrated talent management & 1 & 42,596 & $.405^{\mathrm{a}}$ &, 164 &, 160 &, 405 & $.000^{\mathrm{b}}$ \\
\hline
\end{tabular}

Table 3 shows that all the results are significant - all the talent management factors are significant predictors of motivation. More specifically the results in Table 3 show that:

- Talent Review Processes is a significant positive predictor of Motivation: $F(1,218)$ $=45.285$, and accounted for approximately $41.6 \%$ of the variance of Motivation $\left(R^{2}\right.$ $=.173$, adjusted $R^{2}=.169$ ). The effect was small. 
- Management Commitment is a significant positive predictor of Motivation: $F$ (1, 218) $=60,713$, and accounted for approximately $46.8 \%$ of the variance of Motivation $\left(R^{2}=.219\right.$ adjusted $\left.R^{2}=.21,5\right)$. The effect was small.

- Workforce Planning is a significant positive predictor of Motivation: $F(1,218)$ $=76,102$, and accounted for approximately $51 \%$ of the variance of Motivation $\left(R^{2}=\right.$ $.16 \%$, adjusted $\left.R^{2}=.25,6\right)$. The effect was medium.

- Talent Management Strategy is a significant positive predictor of Motivation: $F$ (1, $218)=64.382$, and accounted for approximately $47.8 \%$ of the variance of Reliability $\left(R^{2}=.229\right.$, adjusted $\left.R^{2}=.113\right)$. The effect was small.

- Talent Outsourcing is a significant positive predictor of Motivation: $F(1,218)=$ 34.442 , and accounted for approximately $37.0 \%$ of the variance of Motivation $\left(R^{2}=\right.$ .137 , adjusted $R^{2}=.169$ ). The effect was small.

- Talent Acquisition was found to be a significant positive predictor of Motivation: $F$ $(1,218)=42.734$, and accounted for approximately $40.6 \%$ of the variance of Motivation $\left(R^{2}=.165\right.$, adjusted $\left.R^{2}=.161\right)$. The effect was small.

- Talent Engagement is a significant positive predictor of Motivation: $F(1,218)=$ 63.418 , and accounted for approximately $47.6 \%$ of the variance of Motivation $\left(R^{2}=\right.$ .226 , adjusted $R^{2}=.223$ ). The effect was small.

- Talent Development is a significant positive predictor of Motivation: $F(1,218)=$ 56.871 , and accounted for approximately $45.6 \%$ of the variance of Motivation $\left(R^{2}=\right.$ .208 , adjusted $\left.R^{2}=.204\right)$. The effect was small.

- Talent Performance is a significant positive predictor of Motivation: $F(1,218)=$ 36.910 , and accounted for approximately $38.1 \%$ of the variance of Motivation $\left(R^{2}=\right.$ .145 , adjusted $\left.R^{2}=.141\right)$. The effect was small.

- Talent Deployment was found to be a significant positive predictor of Motivation: $F$ $(1,218)=47.136$, and accounted for approximately $42.2 \%$ of the variance of Motivation $\left(R^{2}=.178\right.$, adjusted $\left.R^{2}=.175\right)$. The effect was small.

- Talent Retention is a significant positive predictor of Motivation: $F(1,218)=$ 37.318 , and accounted for approximately $38.3 \%$ of the variance of Motivation $\left(R^{2}=\right.$ .147 , adjusted $\left.R^{2}=.143\right)$. The effect was small.

- Integrated Talent Management is a significant positive predictor of Motivation: $F$ (1, $218)=42.596$, and accounted for approximately $40.5 \%$ of the variance of Motivation $\left(R^{2}=.164\right.$, adjusted $\left.R^{2}=.160\right)$. The effect was small.

Based on the results shown in Table 3 , Hypothesis 1 , is accepted, namely there is a significant positive relationship between talent management and motivation. 
The results of the regression analyses between talent management and intention to quit are reported in Table 4 below.

Table 4: Regression Analyses - Talent management and intention to quit

\begin{tabular}{lccccccc}
\hline & Df & $\mathbf{F}$ & $\mathbf{R}$ & $\begin{array}{c}\mathbf{R} \\
\text { Square }\end{array}$ & $\begin{array}{c}\text { Adjusted } \\
\mathbf{R} \text { Square }\end{array}$ & Beta & $\mathbf{p}$ \\
\hline Talent review process & 1 & 2,636 & $.110^{\mathrm{a}}$ &, 012 &, 007 &,- 110 & $.106^{\mathrm{b}}$ \\
Management commitment & 1 & 3,615 & $.128^{\mathrm{a}}$ &, 016 &, 012 &,- 128 &, 059 \\
Workforce planning & 1 & 3,022 & $.117^{\mathrm{a}}$ &, 014 &, 009 &,- 117 &, 084 \\
Talent management strategy & 1 & 1,125 & $.072^{\mathrm{a}}$ &, 005 &, 001 &,- 072 &, 290 \\
Talent outsourcing & 1 & 1,937 & $.094^{\mathrm{a}}$ &, 009 &, 004 &,- 094 & $.165^{\mathrm{b}}$ \\
Talent acquisition & 1 & 2,214 & $.100^{\mathrm{a}}$ &, 010 &, 006 &,- 100 &, 138 \\
Talent engagement & 1 & 1,230 & $.075^{\mathrm{a}}$ &, 006 &, 001 &,- 075 &, 269 \\
Talent development & 1 & 3,321 & $.123^{\mathrm{a}}$ &, 015 &, 011 &,- 123 &, 070 \\
Talent performance & 1 & 3,720 & $.130^{\mathrm{a}}$ &, 017 &, 012 &,- 130 &, 055 \\
Talent deployment & 1 & 4,380 & $.141^{\mathrm{a}}$ &, 020 &, 015 &,- 141 & $.038^{* \mathrm{~b}}$ \\
Talent retention & 1 & 6,819 & $.175^{\mathrm{a}}$ &, 030 &, 026 &,- 175 & $.010^{* \mathrm{~b}}$ \\
Integrated talent management & 1 & 2,099 & $.098^{\mathrm{a}}$ &, 010 &, 005 &,- 098 & $.149^{\mathrm{b}}$ \\
\hline
\end{tabular}

The results in Table 4 show that Talent Development is a significant positive predictor of Intention to Quit: $F(1,218)=3.321$, and accounted for approximately $12.3 \%$ of the variance of Intention to Quit $\left(R^{2}=.006\right.$, adjusted $\left.R^{2}=.001\right)$. The effect was small. Also, the results in Table 4 show that Talent Retention is a significant positive predictor of Intention to Quit: $F(1,218)=6.819$, and accounted for approximately $17.5 \%$ of the variance of employment to quit $\left(R^{2}=.030\right.$, adjusted $\left.R^{2}=.026\right)$. The effect was small.

Based on the results from Table 3, Hypothesis 2, namely that there is a significant positive relationship between talent management and intention to quit, is partially accepted.

The results of the regression analyses between motivation and intention to quit are reported in Table 5 below. 
Table 5: Regression analyses between motivation and intention to quit

\begin{tabular}{llllrrrr}
\hline & Df & F & R & R square & $\begin{array}{c}\text { Adjusted R } \\
\text { square }\end{array}$ & Beta & P \\
& & & & & & & \\
\hline Motivation & 1 & 7,576 & $.184^{a}$ &, 034 &, 029 &,- 184 &, 006 \\
\hline
\end{tabular}

The results in Table 5 show that Motivation is a significant negative predictor of Intention to Quit: $F(1,218)=7.576$, and accounted for approximately $18.4 \%$ of the variance of Intention to Quit ( $R^{2}=.034$, adjusted $R^{2}=.029$ ). The effect was small.

Based on the results from Table 5, Hypothesis 3, namely that there is a significant negative relationship between motivation and intention to quit, is accepted.

The results of the multiple regression between talent management, motivation and intention to quit are reported in Table 6 below. Standard Multiple Regression was performed to determine whether motivation moderated the relationship between Talent management and the Intention to quit. The results of the multiple regression analysis with Talent management and Motivation as independent variables, and the interaction between these variables (to test for moderating effects), and Intention to quit is reported in Table 2 (note: all the independent variables were centred). In models 1 and 2, the effects of the independent variables were entered, while in the third model the interaction term was also entered.

Table 6: Multiple Regression - Talent management, Motivation and Intention to Quit

\begin{tabular}{|c|c|c|c|c|c|c|c|c|}
\hline \multirow[t]{2}{*}{ Model } & \multicolumn{2}{|c|}{$\begin{array}{l}\text { Un-standardised } \\
\text { coefficients }\end{array}$} & $\begin{array}{l}\text { Standardised } \\
\text { coefficients }\end{array}$ & \multirow[t]{2}{*}{$T$} & \multirow[t]{2}{*}{$\begin{array}{l}\mathrm{P} \\
\text { (Sig) }\end{array}$} & \multirow[t]{2}{*}{$\mathrm{R}$} & \multirow[t]{2}{*}{$\mathrm{R}^{2}$} & \multirow[t]{2}{*}{$\Delta \mathrm{R}^{2}$} \\
\hline & B & SE & Beta & & & & & \\
\hline \multicolumn{6}{|c|}{ Talent management and Intention to quit } & $.135^{\mathrm{a}}$ & 0.018 & .014 \\
\hline (Constant) & 4.439 & 0.445 & & 9.974 & 0.000 & & & \\
\hline $\begin{array}{l}\text { Talent } \\
\text { management }\end{array}$ & -.353 & 0.175 & -.135 & -2.014 & 0.045 & & & \\
\hline \multicolumn{6}{|c|}{ Talent management, Motivation and Intention to quit } & $.190^{\mathrm{a}}$ & .036 & .027 \\
\hline (Constant) & 4.911 & .502 & & 9.788 & 0.000 & & & \\
\hline $\begin{array}{l}\text { Talent } \\
\text { management }\end{array}$ & -.144 & 0.204 & -.055 & 0.706 & 0.481 & & & \\
\hline
\end{tabular}




\begin{tabular}{|c|c|c|c|c|c|c|c|c|}
\hline Motivation & -.258 & 0.130 & -.155 & -1.987 & 0.048 & & & \\
\hline \multicolumn{6}{|c|}{ Talent management, Motivation, TLMXMOT and Intention to quit } & $0.287^{a}$ & 0.083 & 0.070 \\
\hline (Constant) & 1.164 & 1.234 & & 0.943 & 0.347 & & & \\
\hline $\begin{array}{l}\text { Talent } \\
\text { management }\end{array}$ & 1.668 & .583 & 0.639 & 2.862 & 0.005 & & & \\
\hline Motivation & 0.738 & .327 & .443 & 2.258 & 0.025 & & & \\
\hline TLMXMOT & -0.456 & .138 & -1.148 & -3.308 & 0.001 & & & \\
\hline
\end{tabular}

From Table 6, it is evident that Talent management explains $13.5 \%$ of the variance in the Intention to quit, while Talent management and Intention to quit combined explains $19 \%$ of the variance Intention to quit. However, adding the interaction of Talent management and Intention to quit in the multiple regression analysis resulted in a significant increase in the explained percentage of variance in the Intention to quit. Motivation, therefore, moderated the relationship between Talent management and Intention to quit.

\section{Discussion}

The main objective of this research was to determine whether leadership talent mind-set is a predictor of motivation and retention of junior correctional officials. The results of this research continue to highlight the lack of talent management and talent management practices in government institutions (Barkhuizen, 2015). Of particular concern was the lack of management commitment towards talent management which in turn had a negative spill over effect on the effective application of other talent management practices. Moreover poor management commitment towards talent also explains the lack of an integrated talent management strategy for junior correctional officials.

As with previous studies the results of this research showed that all talent management practices had a significant positive relationship with the motivation of employees in this study (see Barkhuizen et. al 2015). One possible explanation for this finding is that employees with high levels of intrinsic motivation (as was the case in the present study) might not be affected by external factors such as talent management practices. These results are open for speculation and need further investigation.

In this study, the motivation of employees was negatively related to their intention to quit. This finding confirms previous research which found that highly motivated employees tend to remain in their organisations (Asad \& Dainty, 2005). The results of the present study showed that $75 \%$ of the respondents displayed high levels of motivation. It was also found that motivation moderated the relationship between talent management and 
turnover intentions of the respondents. Therefore, even though talent management practices were found to be poorly applied, junior correctional officials still showed high levels of intrinsic motivation.

This results of the research also revealed the alarming high number of junior correctional officials who considered quitting their profession. All talent management practices were found to be predictors of junior correctional officials' turnover intentions. In line with previous studies poor talent management practices in this study also increased junior correctional officials' intentions to quit their jobs (Du Plessis et al., 2015).

\section{Practical implications}

This study highlighted the poor application of talent management practices among junior correctional officials. Even though the poor application of talent management did not affect the intrinsic motivational levels of these officials, management should take cognizance of the findings of this study, because talent management can influence the turnover intentions of other general groups or those motivated by external factors. Human resource practitioners within the correctional services are encouraged to play a more active role in developing an integrated talent management system that will enhance the performance management, development and succession planning in correctional services.

\section{Limitations and recommendations}

This study had some limitations. Firstly, a cross-sectional research design was followed, which implies that cause-and-effect inferences of the interactive relationships between talent management, motivation and turnover intentions of junior correctional officials cannot be tracked over the longer term. Furthermore, the sample should be expanded in future studies to include other stakeholder groups in the talent management process, such as line management and human resource practitioners, to obtain a more holistic perspective on talent management processes in correctional Services. It would also be of great interest to compare talent management expectations of different generational groups in Correctional Services.

\section{Conclusion}

In conclusion, the research addressed talent management practices among junior correctional officials in the Department Correctional Services, with the intention to ascertain if talent management practices are properly managed. The Department's management is encouraged to assess the current talent management practices and where there are gaps identified, interventions be put in place to address such anomalies. 
Building talent management into the psychological contract and the performance management process will be an important way for the department to ensure that it reaps the benefits of its investment. It is also important that the expectations and obligations of both the department and employees are openly discussed by line managers and employees in order to able to monitor their respective levels of satisfaction. It is of paramount importance for the department to consider that it needs effective correctional officials to succeed in delivering quality services. Lack of talent management may lead to correctional officials leaving the department, including losing the scare skills personnel.

\section{References}

BARKHUIZEN, E., 2015. Talent Management: The Catalyst for the 21st Century Business World.. [Online] Available at: http://www.nwu.ac.za/sites/www.nwu.ac.za/files/files/mc/documents/2015\%20\%20INAUGURAL\%20LECTURE\%20PROF\%20BARKHUIZEN.pdf Reprint 2015

BARKHUIZEN, E.N., SCHUTTE, N.E. and SMIT, A. 2015. Talent management, motivation and service quality of support staff in a public higher education institution.. Journal of Public Administration. 2015, Vol. 50, No. 1, s. 658-673.

BARKHUIZEN, E.N, WELBY-COOKE, G., SCHUTTE, N. and STANZ, K., 2014. Talent Management and Leadership Reciprocity: The case of the South African Aviation Industry. Mediterranean Journal of Social Sciences. 2014, Vol. 5, No. 9, s. 11-17.

BURNS, N. and GROVE, S. 2005. The Practice of Nursing Research: Conduct, Critique, and Utilization. Michigan: Elsevier/Saunders. Reprint 2005.

CAPPELLI, P. 2008. Talent on demand: Managing talent in an uncertain age. Boston, US: Harvard Business Press. Reprint 2008.

CHEESE, P., THOMAS, R. and CRAIG, E. 2008. The Talent Powered Organisation: strategies for globalization, talent management and high performance. London: Kogan Page. Reprint 2008.

CHILOANE, A. and BARKHUIZEN, E.N. 2017. Exploring the relationship between talent management and servuce delivery in a selected government institution. Paper presented at the $34^{\text {th }}$ International Academic Conference, Florence, Italy.

CRAN, C. 2010. 101 Ways to Make Generations X, Y and Zoomers Happy at Work. Canada: Synthesis at Work Inc. Reprint 2010.

DU PLESSIS, L., BARKHUIZEN, E., STANZ, K. and SCHUTTE, N., 2015. The management side of talent: Causal implications for the retention of generation $Y$ employees. The Journal of Applied Business Research. 2015, Vol. 35, No. 1, s. 1767-1780.

EGEROVÁ, D. et al., 2013. Integrated Talent Management: Challenge and Future for Organizations in Visegrad Countries, Czech Republic: NAVA. Reprint 2013.

FIELD, A., 2009. Discovering statistics using SPSS. 3rd ed. London: Sage. Reprint 2009. 
LESENYEHO, D., 2017. Talent management of early career academics in merged South African higher education institutions.. Mmabatho: Department of Industrial Psychology, North-West University. Reprint 2017.

LUBINDA, R., BARKHUIZEN, E. and SCHUTTE, N., 2017. Deconstructing the concept of talent in a selected government institution in Namibia. Paper presented at the $44^{\text {th }}$ Paper presented at $44^{\text {th }}$ International Business Research Conference, Zurich, Switzerland.

MAGOLEGO, H., BARKHUIZEN, E.N. and LESENYEHO, D. 2013. Talent Management and Job Performance: The Mediating Role of Job Satisfaction.Johannesburg, PPBA, s. 132-235.

MASALE, R., BARKHUIZEN, E., MOKGELE, R. and MAKGALA, D. 2016. Talent management as a predictor of employee performance in local government institutions in Botswana. Langebaan, Nelson Mandela Metropolitan University, s. 227-240.

MASSIE, S. 2015. Talent Management: Developing leadership and not just leaders. London: The Kings Fund, Social Care Institute of Excellence. Reprint 2015.

MPOFU, L. 2013. The relationship between talent management, productive organisational energy and turnover intentions of employees in a local government institution. Mmabatho: Department of Industrial Psychology; North-West University. Reprint 2013.

MULLINS, L. and CHRISTY, G. 2013. Management and Organisational Behaviour. London: Pearson. Reprint 2013.

PIENAAR, Y., 2013. A structured model of the relationship between talent mindset, organizational energy and work wellness. Pretoria: Department of Human Resource Management, University of Pretoria. Reprint 2013.

POP, C., SWANEPOEL, S. and BARKHUIZEN, E.N. 2013. The role of mentorship in the retention of graduate interns. Alternations. 2013, Vol. 8, s. 86-106.

SAUROMBE, M. 2015. Talent Management as a predictor of positive work related outcomes for academic staff in South African Higher Education Institutions. Mmabatho: Department of Industrial Psychology, North-West University. Reprint 2015.

SAUROMBE, M., BARKHUIZEN, E.N. and SCHUTTE, N. 2017. Management perceptions of a higher educational brand for the attraction of talented academic staf. SA Journal of Human Resource Management. 2017, Vol. 15, No. 1, s. 1-10.

SCHUTTE, N., BARKHUIZEN, E.N. and VAN DER SLUIS, L. 2015. The validation of a human resource management professional competence model for the South African context. SA Journal of Industrial Psychology. 2015, Vol. 41, No. 1, s. 1-9.

SERVICES, D. O. C., 2016. Annual Report - 2015/ 2016 Financial Year. Pretoria: Department of Correctional Services. Reprint 2016.

SMITH, R., 2015. Talent management - Building the case for direct entry into leadership roles in British policing. The Police Journal: Theory, Practice and Principles. 2015, Vol. 88, No. 2, s. 160-173.

SPSS, 2017. SPSS 24.0 for Windows. Chicago: SPSS Inc. Reprint 2017. 
SWANEPOEL, B., ERASMUS, B. and SCHENK, H. 2014. South African human resource management. Theory and practice. Cape Town: Juta. Reprint 2014.

THERON, M., BARKHUIZEN, E.N. and DU PLESSIS, Y. 2014. Managing the academic talent void: Investigating factors in academic turnover and retention in South Africa. South African Journal of Industrial Psychology. 2014, Vol., 40, No. 1, s. 1-14.

VAN DYK, J. and COETZEE, M. 2012. Retention factors in relation to organisational commitment in medical and information technology services. SA Journal of Human Resource Management. 2012, Vol. 10, No. 2, s.. 1-11. 